\title{
Assessing the growth of Arctic charr (Salvelinus alpinus) (Linnaeus, 1758) in four salinities, under experimental conditions
}

\author{
A. Mardones ${ }^{a, b *}$ (D), R. Vega $a^{a, b}$ (D), F. Encina ${ }^{c, d}$ (D), C. Pichara ${ }^{a}, K$. González ${ }^{e}$ \\ P. De los Rios ${ }^{d, e}$ (D) and B. Peña ${ }^{a}$ \\ aDepartamento de Ciencias Agropecuarias y Acuícolas, Universidad Católica de Temuco, Temuco, Chile

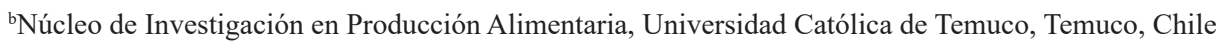 \\ 'Departamento de Ciencias Ambientales, Universidad Católica de Temuco, Temuco, Chile \\ 'Núcleo de Estudios Ambientales, Universidad Católica de Temuco, Temuco, Chile \\ eDepartamento de Ciencias Biológicas y Químicas, Universidad Católica de Temuco, Temuco, Chile \\ *e-mail: mardolaz@uct.cl
}

Received: July 18, 2019 - Accepted: July 30, 2019 - Distributed: November 30, 2020

(With 2 figures)

\begin{abstract}
Studies in Salvelinus alpinus, Arctic charr, indicate that it has a low capacity to hyposmorregulatory or adaption to sea in winter periods in Arctic waters. The investigation finds to determinate the rank optimum of salinity to can cultivate this species at Chile. The weight adequate was determined to join on the sea by analysis of gill $\mathrm{Na}^{+}, \mathrm{K}^{+}$-ATPase activity, that it was found between the ranks $80-130 \mathrm{~g}$, with $14.5 \mathrm{U} / \mathrm{mg}$. It underwent evaluation of fish growth of $72 \mathrm{~g}$ salinities from 0 (control), 18, 25 and $33 \mathrm{~g} / \mathrm{L}$ (sea water) for 94 days. The results indicate that the largest increases were obtained in brackish water. T18 g/L and T25 g/L achieved growth of $25 \%$ and $19 \%$ on day 94 and term sampling respectively. It is important to mention that the $8 \%$ that survived in seawater introduced percentages growth $16.6 \%$ equivalent to brackish water and control. These results suggest that Salvelinus alpinus can grow in seawater, with levels of $\mathrm{Na}^{+}, \mathrm{K}^{+}$-ATPase similar to those submitted by Salmo salar with a weight not less than $80 \mathrm{~g}$.
\end{abstract}

Keywords: Salvelinus alpinus, anadromous, $\mathrm{Na}^{+}, \mathrm{K}^{+}$-ATPase activity, aquaculture, adaptation, hyposmorregulatory.

\section{Avaliando o crescimento do Charr Ártico (Salvelinus alpinus) (Linnaeus, 1758) em quatro salinidades, sob condições experimentais}

\section{Resumo}

Estudos em Salvelinus alpinus, Charr Ártico, indicam que tem baixa capacidade de hiposmorregulação ou adaptação ao mar em períodos de inverno nas águas do Ártico. A investigação determina o melhor nível de salinidade para cultivar esta espécie no Chile. Determinou-se o peso adequado para se unir ao mar pela análise da atividade da $\mathrm{Na}+, \mathrm{K}+$-ATPase das brânquias, que foi encontrada entre as faixas de $80 \mathrm{a} 130 \mathrm{~g}$, com 14,5 U/mg. Foi avaliado o crescimento de $72 \mathrm{~g}$ salinidades de 0 (controle), 18, 25 e $33 \mathrm{~g} / \mathrm{L}$ (água do mar) por 94 dias. Os resultados indicam que os maiores aumentos foram obtidos em água salobra. T18 g/L e T25 g/L alcançaram crescimento de $25 \%$ e $19 \%$ no dia 94 e amostragem a termo, respectivamente. É importante mencionar que os $8 \%$ que sobreviveram na água do mar apresentaram percentuais de crescimento de 16,6\% equivalentes a água salobra e controle. Estes resultados sugerem que o Salvelinus alpinus pode crescer em água do mar, com níveis de $\mathrm{Na}+, \mathrm{K}+$-ATPase semelhantes aos apresentados por Salmo salar com um peso não inferior a $80 \mathrm{~g}$.

Palavras-chave: Salvelinus alpinus, anádromo, atividade de $\mathrm{Na}+, \mathrm{K}+$-ATPase, aqüicultura, adaptação, hiposmorregulador.

\section{Introduction}

Arctic charr, Salvelinus alpinus (Linnaeus, 1758), belongs to the group of circumpolar species of trout. There are anadromous and freshwater populations, purely. It is known because it's phenotypic plasticity, influenced by environmental variations (Hammar et al., 1993). Research in the anadromous variety state that the life strategy involves transforming parr (freshwater) to smolt (saltwater) (Aas-Hansen et al., 2005, 2003).

The interest in growing A. charr started in 1970. Its cultivations have advantages such as its rapid growth in low temperatures to below $5^{\circ} \mathrm{C}$, it is handled at densities above $100 \mathrm{~kg} / \mathrm{m}^{3}$; it has conversion rates close to 1 and has a 
high commercial value (Reynolds, 1994; Summerfelt et al., 2004). The growth of A. charr has been highly variable, due to, probably inappropriate cultivation techniques, season changes, hyposmoregulatory ability and low temperatures existing in winter (Jobling et al., 1998).

This species is considered low salinity tolerance compared with other salmonids (Dempson, 1993). The authors Lysfjord and Staurnes (1998), point out that Arctic anadromous charr has higher levels of $\mathrm{Na}^{+}, \mathrm{K}^{+}$-ATPase migration periods, compared to Atlantic salmon.

Yukon Gold Strain Icy Waters (Arctic charr) Canadian study is a combination of anadromous and freshwater populations. Despite the problems of the species described above, the reason to start assessing the feasibility of cultivation of Arctic charr in brackish and marine waters is that in this environment, the process is more efficient due to it corresponds to the natural cycle of salmonids. Hence, it doubles their body mass in relation to the remaining cohorts in freshwater (Jørgensen et al., 1997; Berrill and McCarthy, 2004), the availability of space is larger, it mitigates the problem of contamination of the wastewater column, as a result of the presence of currents and tides are decreasing or dragging or settleable solids in suspension (Lépez et al., 2004). However, it is uncertain the optimal salinity range and weight required for this species to develop grow and optimize their osmoregulatory capacity.

It will be established the levels of gill $\mathrm{Na}^{+}, \mathrm{K}^{+}$-ATPase of Arctic charr in different sizes to select the range of weight observed a better activity osmoregulatory, in order to define the most appropriate for entry to the sea and then subjected to various salinities. They observe the effect on growth, mortality, and the conversion factor of Arctic charr (Salvelinus alpinus), four salinities $\left(0,18,25,33 \mathrm{gL}^{-1}\right)$, under experimental conditions of cultivation. It is hypothesized that in Chile, Salvelinus alpinus, Yukon Gold strain of Icy Waters, can be grown at sea or brackish water since this country has different environmental conditions from the countries of northern Arctic waters, which may be advantageous to grow.

\section{Material and Methods}

Arctic charr (Salvelinus alpinus), Yukon Gold strain of Icy Waters, 14 months old were used and they had been maintained with 24 hours light photoperiod at a temperature of $8{ }^{\circ} \mathrm{C}$. To meet this aim, the effects produced on the fish's weight and size were assessed. Three treatments of different salinities $\left(18,25\right.$ and $\left.33 \mathrm{gL}^{-1}\right)$ were arranged, with their respective replicas, and 32 individuals per tank. Samples were taken of individual parr spots, weight and height in four periods with an interval of 20 days. As a control, the group was established to the salinity of $0 \mathrm{~g} \mathrm{~L}^{-1}$. Parameters of oxygen saturation, temperature and salinity were registered daily. A 16:8 photoperiod controlled by a timer was applied, simulating natural with fluorescent light lamps.

The specific activity of gill $\mathrm{Na}^{+}, \mathrm{K}^{+}$-ATPase was determined according to the method of Lasserre et al. (1978), as amended by Vial (personal communication) expressed in Umols of $\mathrm{Pi} *$ mg protein- $1 * \mathrm{~h}-1=(\mathrm{U} / \mathrm{mg})$. The same methodology was used 48 hours after the fish were subjected to different salinities and to 94 days, where the experiment was concluded. In addition, sampling weight and size of fish was carried out and parr stains existing were registered and separated by degrees of presentation: NPS: Noticeable Parr stains; STP: slight traces Parr; SILV: Silver. Before moving to marine land base gills sampling were taken on the premises of origin fish farming. It was extracted the first-gill arch 10 individuals per group (20, 60, 100, 140, $180 \mathrm{~g}$; Figure 1).

After 40 days of the first analysis of gill $\mathrm{Na}^{+}, \mathrm{K}^{+}$-ATPase in the fish farming, fish were transferred to the selected size Landbase Ocean, where they were arranged in different salinities. Fish out of $72 \mathrm{~g}$ in weight and $18.5 \mathrm{~cm}$ in length were used, which were arranged randomly between treatments (Control 0, T18, T25 and T33 $\mathrm{gL}^{-1}$ ), keeping them for 14 days in acclimation and adaptation to the new conditions. 32 fish were allocated per pool, obtaining a density of $23 \mathrm{~kg}^{*} \mathrm{~m}^{-3}$, with a flow of $31 / \mathrm{min}$ ensuring saturation of $90 \%$. It was set a network of river water with $0 \mathrm{gL}^{-1}$ and seawater of $33 \mathrm{gL}^{-1}$, and two collection ponds for treatment at 18 and $25 \mathrm{gL}^{-1}$. It's used $12 \mathrm{~m}^{3}$ tanks $0.1,3$ control and 3 for each treatment. Parameters of oxygen saturation, temperature and salinity, were registered daily. It was applied a 16:8 photoperiod controlled by a timer, simulating natural summer with fluorescent light lamps.

The fish were fed pellets containing 26\% lipid and $43 \%$ protein, by manual feeding three times a day. They were fed to satiation, preventing their growth being suppressed, using as a base the chart of Jobling (1990). It was assessed their daily growth by specific growth rate (SGR) as Rowe and Thorpe (1990), and thermal growth coefficient (GF3) in the different treatments (Equations 1, 2 and 3):

$$
\begin{aligned}
& \mathrm{SGR}=(\mathrm{In} \mathrm{FW}-\mathrm{In} \mathrm{IW}) /(\mathrm{D} * 100) \\
& \mathrm{GF} 3=\left(\left(\mathrm{FW}^{(1 / 3)}-\mathrm{IW}^{(1 / 3)}\right) / \mathrm{TUA}\right) * 1000
\end{aligned}
$$

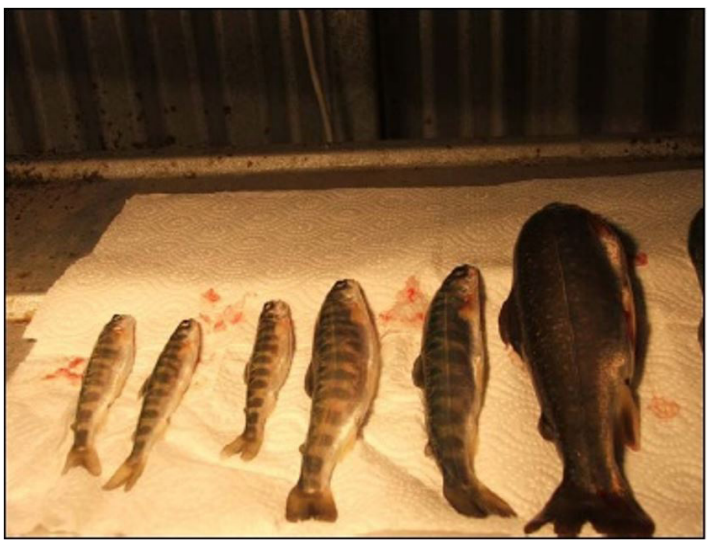

Figure 1. Parr spots observed in fish from 20, 60, 100, 140 and $180 \mathrm{~g}$. 
where: $\mathrm{FW}=$ final weight; $\mathrm{IW}=$ initial weight; $\mathrm{TUA}=$ thermal units accumulated during the period; $\mathrm{L}=$ length; $\mathrm{D}=$ Day.

$$
\mathrm{K}=\left(\mathrm{W} / \mathrm{L}^{3}\right) * 100
$$

where: $\mathrm{K}=$ condition factor (Fulton index); $\mathrm{W}=$ fish weight; $\mathrm{L}=$ length; 3 = Isometric growth constant.

To determine the stress methods such as determination of glucose, leukocyte count, red cell count, differential leucocyte count and erythrocyte were used. The experiment results are expressed as the mean of data and respective standard errors. The assumptions of normality and homogeneity of variance will be tested prior to analysis of variance (ANOVA) and the differences between groups will be determined by Tukey's multiple comparison test (Zar, 1999). The construction of databases and information management was done in an Excel spreadsheet while the descriptive analysis and statistical tests were performed using SPSS 12.0 for Windows.

\section{Results}

Levels of gill $\mathrm{Na}^{+}, \mathrm{K}^{+}$-ATPase from 8.7 to $14.5 \mathrm{U} / \mathrm{mg}$ in weights from 95 to $193 \mathrm{~g}$ were found respectively. The highest values occurred in the weights $60,100,140 \mathrm{~g}$ with $12.6-14.4$ to $11.2 \mathrm{U} / \mathrm{mg}$. This suggests that the group to move to the sea should be between $80-130 \mathrm{~g}$. The sizes that got high levels of gill $\mathrm{Na}^{+}, \mathrm{K}^{+}$-ATPase had NSS (Table 1).

The levels of gill $\mathrm{Na}^{+}, \mathrm{K}^{+}$-ATPase of the selected fish taken to land base ocean were lower than those obtained in July for the same size (less than $10 \mathrm{U} / \mathrm{mg}$ ). The lowest rates were in $\mathrm{T} 25$ and $\mathrm{T} 33$ salinities $\mathrm{gL}^{-1}$ of salinity (5.96 and $5.40 \mathrm{U} / \mathrm{mg}$ ), respectively, with meaningful differences $(\mathrm{P}<0.05)$ compared to $\mathrm{T} 18(9.70 \mathrm{U} / \mathrm{mg})$, being the closest value to that obtained in July (Table 2), presenting NSS (Table 1). However, the control did not present any significantly different $(\mathrm{P}>0.05)$ with the treatment, obtaining values of $(7.61 \pm 1.96 \mathrm{U} / \mathrm{mg})$. The results indicate that Arctic charr decreased its levels of gill $\mathrm{Na}^{+}, \mathrm{K}^{+}$-ATPase during the 40 days from July to late August (reverted). The levels of gill $\mathrm{Na}^{+}, \mathrm{K}^{+}$-ATPase at the end of the research were higher than the values shown at the start of the experiment (Table 2). The T33 treatment showed values of $13.75 \mathrm{U} / \mathrm{mg}$, significantly higher at $(\mathrm{P}<0.05)$, compared to the treatment presented T18 $9.31 \mathrm{U} / \mathrm{mg}$. Control and T25 showed no meaningful difference $(\mathrm{P}>0.05)$ regarding treatment T33. It is important to state that at the end of the experiment the fish of brackish and seawater were silver (Figure 2). However, the analysis carried out to the Arctic charr that got less opportunity for growth, had lower levels of gill $\mathrm{Na}^{+}, \mathrm{K}^{+}$-ATPase and NSS (Table 3), to those in the average population of each treatment.

During the first 48 hours, there were no mortalities. In the following days, mortality was recorded only in the treatment of seawater T33. The survival was obtained in $8 \%$ (8 live fish), compared to the control, T18 and T25 were $100 \%$ survival.

The main external and internal pathological observations of mortalities occurring in seawater were; External (slight desquamation, bleeding cranial area, nostrils, eyes, fins operculum, mouth and anus hyperemic), internal (pale heart, stomach out of breath, external bleeding intestine, congested and inflamed pyloric caeca, bleeding liver, splenomegaly spleen, renomegaly kidney (BKD), swim bladder and haemorrhage brain). It is important to establish that during the experiment the fish were infected with infectious pancreatic necrosis (IPN).

The growth and higher conversion factors were achieved in brackish water (18 and $25 \mathrm{gL}^{-1}$ ) with 24.9 and $19.9 \%$ growth, showing significant differences $(\mathrm{P}<0.05)$, compared to $\mathrm{T} 33 \mathrm{gL}^{-1}$ in the first sampling period. However T33 treatment survived eight fish that showed a $16.6 \%$ increase, equivalent to all treatments in the last sampling period (Table 4). It is

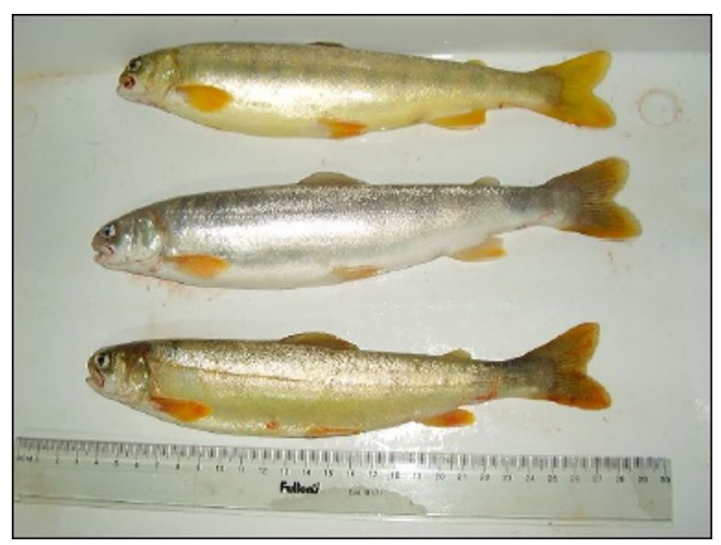

Figure 2. Silvery fish obtained in $\mathrm{H} 2 \mathrm{O}$ from sea at the end of the experiment.

Table 1. First assessment of levels of gill $\mathrm{Na}^{+}, \mathrm{K}^{+}$-ATPase in Arctic charr groups by weight ranges in fish farming.

\begin{tabular}{cccccc}
\hline Group & $\begin{array}{c}\text { Length } \\
(\mathbf{c m})\end{array}$ & $\begin{array}{c}\text { Weight } \\
\mathbf{( g )}\end{array}$ & $\mathbf{K}$ & $\begin{array}{c}\text { Features } \\
\text { External }\end{array}$ & $\begin{array}{c}\text { Specific Activity } \\
\mathbf{g i l l}_{\mathbf{N a}}^{+} \mathbf{\mathbf { K } ^ { + } -} \\
\mathbf{A T P a s e}(\mathbf{U} / \mathbf{m g})\end{array}$ \\
\hline 20 & $14.0 \pm 1.0$ & $23.5 \pm 5.3$ & $0.6 \pm 0.2$ & $\mathrm{NSS}$ & $9.6 \pm 2.4$ \\
60 & $19.4 \pm 0.5$ & $60.0 \pm 7.1$ & $0.7 \pm 0.1$ & $\mathrm{NSS}$ & $12.6 \pm 2.6$ \\
100 & $22.1 \pm 0.8$ & $95.5 \pm 7.2$ & $0.7 \pm 0.1$ & $\mathrm{NSS}$ & $14.5 \pm 4.5$ \\
140 & $24.2 \pm 2.3$ & $137.7 \pm 9$ & $0.4 \pm 0.4$ & $\mathrm{SS}$ & $11.2 \pm 5.7$ \\
180 & $26.7 \pm 2.6$ & $193.0 \pm 37$ & $0.7 \pm 0.3$ & $\mathrm{SS}$ & $8.7 \pm 2.5$ \\
\hline
\end{tabular}

NSS $=$ Notorious spots to see; $\mathrm{SS}=$ Slight spots. 


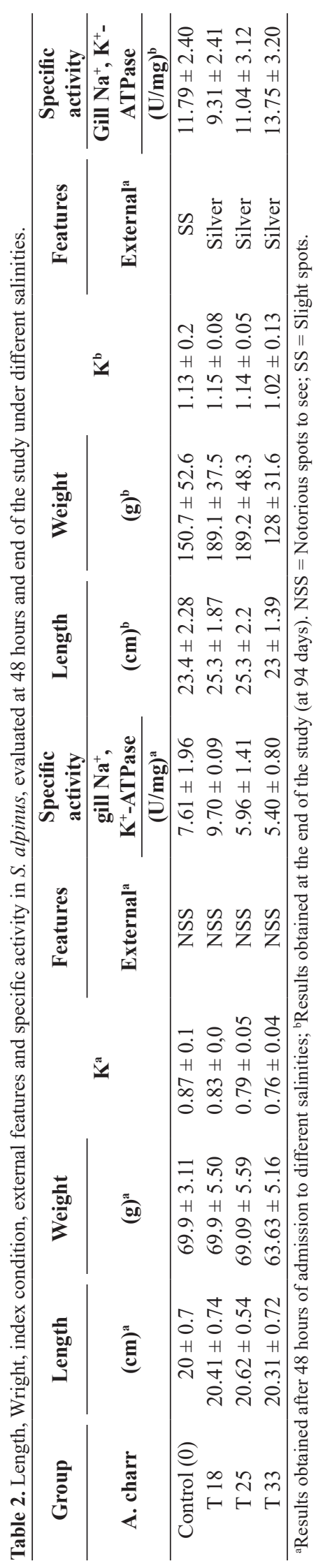


Table 3. Levels of gill $\mathrm{Na}^{+}, \mathrm{K}^{+}$-ATPase at the end of the study of S. alpinus less opportunity for growth (at 94 days of study).

\begin{tabular}{|c|c|c|c|c|c|}
\hline Group & Length & Weight & & Features & Specific activity \\
\hline A. charr & (cm) & (g) & $\mathbf{K}$ & External & $\begin{array}{c}\text { Gill Na } \mathbf{N a}^{+} \text {-ATPase } \\
(\mathrm{U} / \mathrm{mg})\end{array}$ \\
\hline Control (0) & $20.05 \pm 0.45$ & $64.4 \pm 3.36$ & $0.80 \pm 0.06$ & NSS & $09.24 \pm 2.00$ \\
\hline $\mathrm{T} 18$ & $20.34 \pm 0.42$ & $66.6 \pm 12.97$ & $0.79 \pm 0.12$ & NSS & $07.60 \pm 1.43$ \\
\hline $\mathrm{T} 25$ & $20.28 \pm 0.63$ & $72 \pm 11.45$ & $0.86 \pm 0.07$ & NSS & $10.16 \pm 2.21$ \\
\hline
\end{tabular}

NSS $=$ Notorious spots to see.

Table 4. Growth range got during the study.

\begin{tabular}{|c|c|c|c|c|c|}
\hline Media control & Period 0 & Period 1 & Period 2 & Period 3 & Period 4 \\
\hline $\mathrm{W}$ & $72.1 \pm 6.5$ & $73 \pm 7.8$ & $78.2 \pm 15.8$ & $91.4 \pm 28.1$ & $110.6 \pm 42$ \\
\hline $\mathrm{L}$ & $20.5 \pm 0.6$ & $19.8 \pm 0.7$ & $20.1 \pm 1.0$ & $20.8 \pm 1.3$ & $22.1 \pm 2.1$ \\
\hline $\mathrm{K}$ & $0.8 \pm 0.1$ & $0.9 \pm 0.1$ & $1.0 \pm 0.1$ & $1.0 \pm 0.2$ & $1.0 \pm 0.2$ \\
\hline SGR Control & & $0.1 \pm 0.0$ & $0.3 \pm 0.3$ & $0.8 \pm 0.4$ & $1.0 \pm 0.4$ \\
\hline GF3 Control & & $0.1 \pm 0.1$ & $0.5 \pm 0.4$ & $1.1 \pm 0.6$ & $1.2 \pm 0.6$ \\
\hline FCR economic & & $2.5 \pm 2.8$ & $1.4 \pm 2.9$ & $1.5 \pm 1.2$ & $1.4 \pm 0.6$ \\
\hline$\%$ weight & & $1.4 \pm 0.9$ & $6.8 \pm 5.0$ & $14.4 \pm 6.8$ & $17.4 \pm 11.3$ \\
\hline \multicolumn{6}{|l|}{ Media T 18} \\
\hline W & $72.1 \pm 6.5$ & $80.2 \pm 15.2$ & $95.7 \pm 30.1$ & $120.6 \pm 40.9$ & $160.6 \pm 55.2$ \\
\hline $\mathrm{L}$ & $20.5 \pm 0.6$ & $20.3 \pm 0.9$ & $20.8 \pm 1.5$ & $21.9 \pm 2.0$ & $24.1 \pm 2.5$ \\
\hline $\mathrm{K}$ & $0.8 \pm 0.1$ & $0.9 \pm 0.1$ & $1.0 \pm 0.2$ & $1.1 \pm 0.2$ & $1.1 \pm 0.1$ \\
\hline SGR T 18 & & $0.5 \pm 0.2$ & $0.9 \pm 0.2$ & $1.2 \pm 0.1$ & $1.4 \pm 0.3$ \\
\hline GF3 T 18 & & $0.7 \pm 0.2$ & $1.2 \pm 0.2$ & $1.6 \pm 0.2$ & $1.9 \pm 0.4$ \\
\hline FCR economic & & $1.6 \pm 0.4$ & $1.3 \pm 0.1$ & $1.4 \pm 0.1$ & $1.3 \pm 0.5$ \\
\hline$\%$ weight & & $11.4 \pm 3.3$ & $19.4 \pm 2.8$ & $20.6 \pm 2.4$ & $24.9 \pm 5.4$ \\
\hline \multicolumn{6}{|l|}{ Average T 25} \\
\hline W & $72.1 \pm 6.5$ & $83.3 \pm 15.5$ & $96.5 \pm 28.6$ & $119.9 \pm 41.5$ & $149.7 \pm 55.3$ \\
\hline $\mathrm{L}$ & $20.5 \pm 0.6$ & $20.2 \pm 0.9$ & $21.1 \pm 1.3$ & $22.1 \pm 1.9$ & $22.5 \pm 2.3$ \\
\hline $\mathrm{K}$ & $0.8 \pm 0.1$ & $1.0 \pm 0.1$ & $1.0 \pm 0.1$ & $1.1 \pm 0.2$ & $1.1 \pm 0.2$ \\
\hline SGR T 25 & & $0.7 \pm 0.2$ & $0.7 \pm 0.1$ & $1.1 \pm 0.2$ & $1.1 \pm 0.3$ \\
\hline GF3 T 25 & & $0.9 \pm 0.2$ & $1.0 \pm 0.1$ & $1.4 \pm 0.2$ & $1.4 \pm 1.3$ \\
\hline FCR economic & & $1.2 \pm 0.3$ & $1.4 \pm 0.1$ & $1.3 \pm 0.1$ & $1.6 \pm 0.1$ \\
\hline$\%$ growth & & $15.7 \pm 3.3$ & $15.9 \pm 1.3$ & $19.5 \pm 2.8$ & $19.9 \pm 4.6$ \\
\hline \multicolumn{6}{|l|}{ Average T 33} \\
\hline W & $72.1 \pm 6.5$ & $64.1 \pm 8.2$ & $66.9 \pm 17.5$ & $106.7 \pm 24.3$ & $128.0 \pm 31.7$ \\
\hline $\mathrm{L}$ & $20.5 \pm 0.6$ & $19.0 \pm 0.6$ & $20.0 \pm 0.9$ & $21.9 \pm 1.1$ & $22.9 \pm 1.4$ \\
\hline $\mathrm{K}$ & $0.8 \pm 0.1$ & $0.8 \pm 0.1$ & $0.8 \pm 0.1$ & $1.0 \pm 0.1$ & $1.0 \pm 0.1$ \\
\hline SGR T 33 & & $-0.6 \pm 0.2$ & $0.2 \pm 0.3$ & 0.2 & 0.9 \\
\hline GF3 T 33 & & $-0.7 \pm 0.2$ & $0.2 \pm 0.4$ & 0.3 & 1.1 \\
\hline FCR economic & & $-0.7 \pm 0.2$ & $-0.3 \pm 0.1$ & 1.7 & 2.1 \\
\hline$\%$ growth & & $-12.3 \pm 4.3$ & $-19.7 \pm 6.8$ & 4.4 & 16.6 \\
\hline
\end{tabular}

noteworthy that the control showed no significant differences $(\mathrm{P}>0.05)$ with no treatment at the end of the study. In Table 4, shows that the highest SGR - I present GF3 T18 treatment, while the lowest values were obtained in treating seawater.

The $\mathrm{FCR}_{\mathrm{E}}$ showed no significant differences between the treatments $(\mathrm{P}>0.05)$, it is important to note that there is great variability of data. The highest value was found in seawater $\mathrm{FCR}_{\mathrm{E}}$ of 2.1 (Table 4).
The stress level was studied using glucose levels, which at the end of the study showed no significant differences $(\mathrm{P}>0.05)$, being within the allowed ranges for salmonids (Table 5). The results of erythrocytes and leukocytes, as well as glucose, are within the ranges established. However, levels of immature and mature erythrocytes show that $S$. alpinus in the different treatments are slightly stressed (Table 5). 
Table 5. Glucose levels erythrocytes and leukocytes presented by S. alpinus end of the study.

\begin{tabular}{|c|c|c|c|c|c|}
\hline \multirow{2}{*}{ Treatments } & \multirow{2}{*}{$\begin{array}{c}\text { Glucose } \\
\mathrm{mg} / \mathrm{L} \\
\end{array}$} & \multirow{2}{*}{$\begin{array}{c}\text { Erythrocyte } \\
10^{6} / \mathbf{m m}^{3}\end{array}$} & \multirow{2}{*}{$\begin{array}{c}\text { Leucocyte } \\
10^{3} / \mathrm{mm}^{3}\end{array}$} & \multicolumn{2}{|c|}{ Erythrocyte } \\
\hline & & & & Immature & Mature \\
\hline Control $\left(\mathrm{H}_{2} \mathrm{O} \mathrm{FW}\right)$ & $793.7 \pm 18.20$ & $0.80 \pm 0.49$ & $08.47 \pm 5.44$ & $4.87 \pm 3.33$ & $95.13 \pm 3.33$ \\
\hline T18 & $90.39 \pm 20.05$ & $1.29 \pm 0.31$ & $13.86 \pm 4.78$ & $3.71 \pm 3.33$ & $96.29 \pm 3.33$ \\
\hline $\mathrm{T} 25$ & $85.36 \pm 14.79$ & $0.99 \pm 0.18$ & $06.93 \pm 3.15$ & $4.05 \pm 3.15$ & $95.95 \pm 3.15$ \\
\hline $\mathrm{T} 33\left(\mathrm{H}_{2} \mathrm{O} \mathrm{SW}\right)$ & $84.54 \pm 15.90$ & $0.69 \pm 0.15$ & $12.60 \pm 5.02$ & $4.98 \pm 2.29$ & $95.02 \pm 2.29$ \\
\hline
\end{tabular}

\section{Discussion}

The possibility of growing Salvelinus alpinus to different salinities was evaluated, since; there was no clarity on its ability to adapt to osmoregulation or brackish water - seawater. It should be noted that A. charr is a fish diadrómica behaviour and its origin of Icy water has aquacultural and anadromous sweet strains (Lundrigan et al., 2005). Prior to the completion of this experiment, only Chile has carried out the cultivation of this species in freshwater.

The high levels of gill $\mathrm{Na}^{+}, \mathrm{K}^{+}$-ATPase $(14.5 \mathrm{U} / \mathrm{mg})$ in S. alpinus previously performed the experiment between the sizes 80-130 g in the month of July, showed the possibility of migration of the species to water with higher salinity. This coincides with results reported by Lysfjord and Staurnes (1998), Eliassen et al. (1998), that optimal levels of gill $\mathrm{Na}^{+}, \mathrm{K}^{+}$-ATPase would be $12 \mathrm{U} / \mathrm{mg}$, similar to levels of Salmo salar. In September, the date of transfer of Arctic charr to the experimental station Quillaipe, low levels of gill $\mathrm{Na}^{+}, \mathrm{K}^{+}$-ATPase were obtained in fish with an average weight of $72 \mathrm{~g}$ used in the study, which did not correspond to the levels already seen in the size $60 \mathrm{~g}(12 \mathrm{U} / \mathrm{mg})$ (Table 1). This may be because the species imported, have exchanged their life cycle, since the dates of emigration would be in the months of June to July in the northern hemisphere (Finstad et al., 1989; Lysfjord and Staurnes, 1998; Gulseth et al., 2001), this can be explained by a reversal of smoltification suffered by individuals (Aas-Hansen et al., 2005). It is important to establish that there was no monitoring in the previous months to get curve levels of smoltification with gill $\mathrm{Na}^{+}, \mathrm{K}^{+}$-ATPase, indicating the maximum threshold to be transferred to the sea.

Arctic charr during the first assessment of gill $\mathrm{Na}^{+}, \mathrm{K}^{+}$-ATPase showed NSS gill weight ranges between 20 to $100 \mathrm{~g}$ LMP from 140 to $180 \mathrm{~g}$. These data are confirmed, since at the beginning of the experiment $\mathrm{A}$. charr presented NSS in the weighted average of $72 \mathrm{~g}$ and did not decrease its condition rate when levels of gill $\mathrm{Na}^{+}, \mathrm{K}^{+}$-ATPase were within accepted ranges to be moved to higher salinity waters. This showed that external morphological parameters would not be more assertive to define a true smolt. The above coincides with that expressed by Damsgard (1991), who mentions that the visual characteristics of a smolt are not as influential as the physiological characteristics of the same fish. Furthermore, Johnsen et al. (2000), states that both physiological factors and size are involved in the migration to the sea, being decisive for resistance to seawater in this species. Jonsson and Antonsson (2005) states that $10.1 \mathrm{~cm}$ fish have been found migrating to seawater, being close to the lakes.

The smoltification process for salmonids depends on environmental factors that directly affect, photoperiod and temperature. In the process of evaluation of the growth of S. alpinus was not considered a photoperiod regime since they went from 24 hours light to 16 hours of light natural photoperiod (winter). This could directly affect the low levels of gill $\mathrm{Na}^{+}, \mathrm{K}^{+}$-ATPase found 48 post admission to different salinities. Johnsen et al. (2000), mentions that constant photoperiods increase levels of gill $\mathrm{Na}^{+}, \mathrm{K}^{+}$-ATPase, but these would not be enough to be tolerated in seawater. According to Hoar et al. (1992), the constant photoperiod affects growth and the fish excitability, indicating the presence of disturbed endocrine physiology. $\mathrm{He}$ also states that the opposition to the natural sequence in smoltification, the fish under a constant photoperiod developed a high condition factor (related to weight and length) in fresh water, while at sea it grew much slower, ate less and presented fewer efficiencies feed conversion.

During the study, the growth factor SGR, GF3 was increasing in each sample, this may be due to the adjustment period of S. alpinus is slow, and the impact that caused the abrupt transfer to different salinities. However, recent growth results (Table 4 ) of the species concerning salinities of $0,18,25$ and $33 \mathrm{gL}^{-1}$ would be very close to the production parameters obtained in other studies. Arnesen et al. (1993), in their experiment conducted in Norway reveal that the growths of $S$. alpinus abruptly transferred to salinities of $0,20,25,30$ and $35 \mathrm{gL}^{-1}$ obtained a SGR of 1.15, 1.19, 1.26, 1.01, 1.13\%/day. The average levels of glucose made by A. charr are within the parameters permitted by rainbow trout from $41-151 \mathrm{mg} / \mathrm{L}^{-1}$ (Table 5). However individual values would control the lower limit of the range, so that would infer that such fish in starvation (Schreck and Moyle, 1990).

Brown (1993) establishes that blood parameter may be affected by factors such as age, sex, diet, species, time of year, temperature and osmotic changes. This is confirmed by the results of reading the mature and immature erythrocytes since values of $95 \%$ and $4 \%$ mature erythrocytes leave evidence of immature fish that were slightly stressed either by environmental factors, osmotic or disease. According to the results of Rivera (2005) in rainbow trout fish with 95 to $96 \%$ of mature erythrocytes and 4.5 to $4.8 \mathrm{mg} / \mathrm{L}$ of oxygen, would be slightly stressed (monoxide). 


\section{Acknowledgements}

The present study was founded by Fundación Chile and projects FONDEF - CONICYT D06i1028.

\section{References}

AAS-HANSEN, Ø., JOHNSEN, H.K., VIJAYAN, M.M. and JØRGENSEN, E.H., 2003. Development of seawater tolerance and concurrent hormonal changes in fed and fasted Arctic charr at two temperature regimes. Aquaculture, vol. 222, no. 1-4, pp. 145-148. http://dx.doi.org/10.1016/S0044-8486(03)00107-8.

AAS-HANSEN, Ø., VIJAYAN, M.M., JOHNSEN, H.K., CAMERON, C. and JØRGENSEN, E.H., 2005. Resmoltification in wild, anadromous Arctic char (Salvelinus alpinus): a survey of osmoregulatory, metabolic, and endocrine changes preceding annual seawater migration. Canadian Journal of Fisheries and Aquatic Sciences, vol. 62, no. 1, pp. 195-204. http://dx.doi. org/10.1139/f04-186.

ARNESEN, A.M., JØRGENSEN, E.H. and JOBLING, M., 1993. Feed intake, growth and osmoregulation in Arctic charr, Salvelinus alpinus (L.), following an abrupt transfer from freshwater to more saline water. Aquaculture, vol. 114, no. 3/4, pp. 327-338. http:// dx.doi.org/10.1016/0044-8486(93)90307-K.

BERRILL, I. and MCCARTHY, I., 2004. Arctic charr: the aquaculture potential of indigenous Welsh Arctic charr, Salvelinus alpinus. Aquaculture News, 31 december.

BROWN, L., 1993. Aquaculture for veterinarians: fish husbandry and medicine. New York: Pergamon Press, 447 p.

DAMSGARD, B., 1991. Smolting characters in anadromous and resident Arctic charr, Salvelinus alpinus (L.). Journal of Fish Biology, vol. 39, no. 5, pp. 765-774. http://dx.doi. org/10.1111/j.1095-8649.1991.tb04406.x.

DEMPSON, J.B., 1993. Salinity tolerance of freshwater acclimated, small-sized Arctic charr, Salvelinus alpinus from northern Labrador. Journal of Fish Biology, vol. 43, no. 3, pp. 451-462. http://dx.doi.org/10.1111/j.1095-8649.1993.tb00580.x.

ELIASSEN, R.A., JOHNSEN, H.K., MAYER, I. and JOBLING, M., 1998. Contrasts in the osmoregulatory capacity of two Arctic charr, Salvelinus alpinus (L.), strains from northern Norway. Aquaculture, vol. 168, no. 1-4, pp. 255-269. http://dx.doi. org/10.1016/S0044-8486(98)00353-6.

FINSTAD, B., NILSSEN, K.J. and ARNESEN, A.M., 1989. Seasonal changes in sea-water tolerance of Arctic charr (Salvelinus alpinus). Journal of Comparative Physiology, vol. 159, no. 4, pp. 371-378. http://dx.doi.org/10.1007/BF00692408.

GULSETH, O.A., NILSSEN, K.J., IVERSEN, M. and FINSTAD, B., 2001. Seawater tolerance in first-time migrants of anadromous Arctic charr (Salvelinus alpinus). Polar Biology, vol. 24, no. 4, pp. 270-275. http://dx.doi.org/10.1007/s003000000208.

HAMMAR, J., LARSSON, P. and KLAVINS, M., 1993. Accumulation of persistent pollutants in normal and dwarfed Arctic charr (Salvelinus alpinus sp. complex). Canadian Journal of Fisheries and Aquatic Sciences, vol. 50, no. 12, pp. 2574-2580. http://dx.doi.org/10.1139/f93-281.

HOAR, W., RANDALL, D. and FARREL, A., 1992. Fish physiology. San Diego: Academic Press, 474 p.

JOBLING, M., 1990. Fulfilling the impossible dream. Fish Farmer, no. Jul-Aug, pp. 52-53.
JOBLING, M., TVEITEN, H. and HATLEN, B., 1998. Cultivation de Arctic charr: on update. Aquaculture International, vol. 6, no. 3, pp. 181-196. http://dx.doi.org/10.1023/A:1009246509657.

JOHNSEN, H.K., ELIASSEN, R.A., SAETHER, B.S. and LARSEN, J.S., 2000. Effects of photoperiod manipulation on the development of seawater tolerance in Arctic charr. Aquaculture, vol. 189, no. 1/2, pp. 177-188. http://dx.doi.org/10.1016/S00448486(00)00370-7.

JONSSON, I.R. and ANTONSSON, T., 2005. Emigration of age-1 Arctic charr, Salvelinus alpinus, into a brackish lagoon. Environmental Biology of Fishes, vol. 74, no. 2, pp. 195-200. http://dx.doi.org/10.1007/s10641-005-7693-0.

JØRGENSEN, E.H., JOHANSEN, S.J. and JOBLING, M., 1997. Seasonal patterns of growth, lipid deposition and lipid depletion in anadromous Arctic charr. Journal of Fish Biology, vol. 51, no. 2, pp. 312-326. http://dx.doi.org/10.1111/j.1095-8649.1997.tb01668.x.

LASSERRE, P., BOEUF, G. and HARACHE, Y., 1978. Osmotic adaptation of Oncorhynchus kisutch Walbaum. I. Seasonal variations of gills $\mathrm{Na}^{+} / \mathrm{K}^{+}$ATPase activity in Coho salmon, 0 -age and yearling, reared in fresh water. Aquaculture, vol. 14, no. 4, pp. 365-382. http://dx.doi.org/10.1016/0044-8486(78)90019-4.

LÉPEZ, I., WERLINGER, C., KLEMPAU, A. and SOBARZO, G., 2004. Acuicultura: cultivo y producción de organismos acuáticos. In: C. WERLINGER, ed. Biología marina y oceanografia: conceptos y procesos. Concepción: Universidad de Concepción, vol. 2, pp. 559-585.

LUNDRIGAN, T.A., REIST, J.D. and FERGUSON, M.M., 2005. Microsatellite genetic variation within and among Arctic charr (Salvelinus alpinus) from aquaculture and natural populations in North America. Aquaculture, vol. 244, no. 1/4, pp. 63-75. http:// dx.doi.org/10.1016/j.aquaculture.2004.11.027.

LYSFJORD, G. and STAURNES, M., 1998. Gill $\mathrm{Na}^{+}-\mathrm{K}^{+}$-ATPase activity and hyposmoregulatory ability of seaward migrating smolts of anadromous Atlantic salmon (Salmo salar), sea trout (Salmo trutta) and Arctic char (Salvelinus alpinus) in the Hals river, northern Norway. Aquaculture, vol. 168, no. 1, pp. 279-288. http://dx.doi.org/10.1016/S0044-8486(98)00355-X.

REYNOLDS, J.B., 1994. Northern charrs: scientific challenges and management opportunities. Transactions of the American Fisheries Society, vol. 123, no. 3, pp. 368-369. http://dx.doi. org/10.1577/1548-8659(1994)123<0368:NCSCAM>2.3.CO;2.

RIVERA, A., 2005. Evaluación del estado de salud y resistencia al estrés en Trucha arcoiris (Oncorhynchus mykiss) alimentadas con dietas en base a harina de algas (Macrocystis pyrifera). Temuco: Facultad de Recursos Naturales, Universidad Católica de Temuco, 80 p. Tesis de Grado.

ROWE, D.K. and THORPE, J.E., 1990. Differences in growth between maturing and non-maturing male Atlantic salmon, Salmo salar L., parr. Journal of Fish Biology, vol. 36, no. 5, pp. 643-658. http://dx.doi.org/10.1111/j.1095-8649.1990.tb04319.x.

SCHRECK, C. and MOYLE, P., 1990. Methods for fish biology. USA: Exxon Company, 489 p.

SUMMERFELT, S.T., WILTON, G., ROBERTS, D., RIMMER, T. and FONKALSRUD, K., 2004. Developments in recirculating systems for Arctic char culture in North America. Aquacultural Engineering, vol. 30, no. 1-2, pp. 31-71. http://dx.doi.org/10.1016/j. aquaeng.2003.09.001.

ZAR, J., 1999. Biostatistical analysis. New Jersey: Prentice Hall, $661 \mathrm{p}$. 